\title{
Structural evolution of Variegated Glacier, Alaska, U.S.A., since 1948
}

\author{
WENDY LAWSON \\ Department of Geography, University of Canterbury, Private Bag 4800, Christchurch, New Zealand
}

\begin{abstract}
An excellent photographic database, comprising 12 sets of vertical aerial photographs taken between 1948 and 1983, has enabled the structural glaciology of surge-type Variegated Glacier, Alaska, U.S.A., to be analyzed for a period that spans two surge cycles and includes the effects of three surges. The glacierwide patterns of crevasse development at the end of each of these surges, which occurred in 1947-48, $1964-65$ and 1982 83, were remarkably similar, despite differences in surge intensities and extents. At the end of each surge a three-fold longitudinal zonation of crevasse orientation characterised that part of the glacier that had been affected by surge activity. This zonation comprises: (i) transverse crevasses in a narrow upper zone, (ii) superimposed longitudinal and transverse crevasses in an extensive middle zone, and (iii) longitudinal crevasses in a narrow lower zone. The main difference between patterns produced by successive surges was small variations in the extent of the three zones. During quiescence, the most intense crevasse development occurs in the upper glacier in the latter part of quiescence, and is a function of increasingly steep down-glacier velocity gradients developing in the buildup to the impending surge. Some crevassing also develops in the central part of the glacier in mid-quiescence that is not related to the surge nature of the glacier, but to normal flow processes over bedrock. There is no structural evidence to indicate that any of the tributaries of Variegated Glacier surge. This observation suggests that the bulb-like loops in the medial moraines at Variegated Glacier form during quiescence as a result of the steady flow of the tributaries into the stagnant trunk glacier, rather than as a result of tributary surges.
\end{abstract}

\section{INTRODUCTION}

Variegated Glacier, Alaska, U.S.A. (Fig. 1), has become the best-known surge-type glacier in the English-speaking world since its most recent surge, in 1982 - 83, and the latter half of the preceding phase of quiescence, from 1973 onwards, were studied intensively by personnel mainly from the Universities of Washington and Alaska Fairbanks, the U.S. Geological Survey and the California Institute of Technology. During this period, field observations were made of the structural assemblages and the tectonic processes that occurred in various parts of Variegated Glacier and at various stages of its surge cycle. These structural studies include a detailed syntectonic analysis of surge-phase tectonic processes (Sharp and others, 1988), a comprehensive structural analysis in the years following the 1982-83 surge (Lawson, 1989; Lawson and others, 1994), a map of structures found in the terminal lobe during mid-quiescence (personal communication from A. Post, 1986) and a detailed analysis of a particular surge-related structure (Pfeffer, 1992).

This paper enlarges upon the scope of the previous

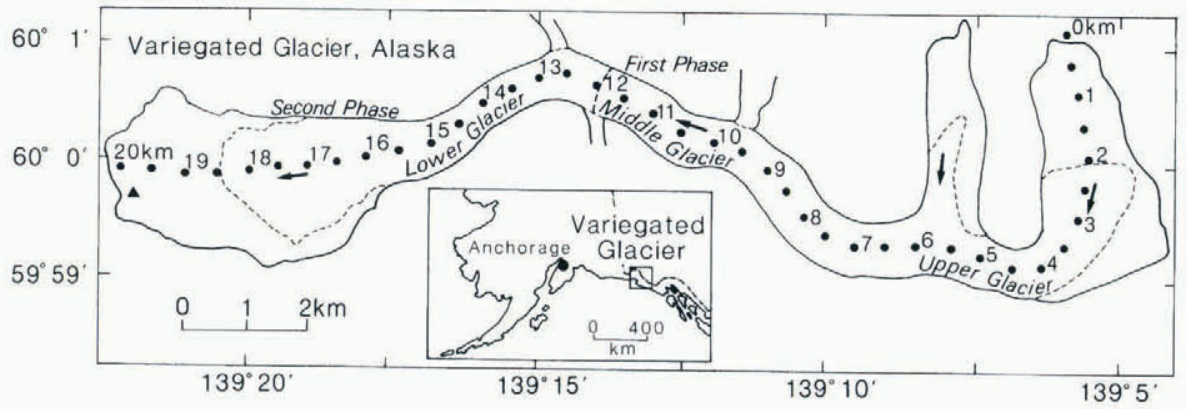

Fig. 1. Map of Variegated Glacier, showing location of the glacier, distances along the centre line from the head of the glacier, and limits of the effects of the 1982-83 surge (dashed lines). 

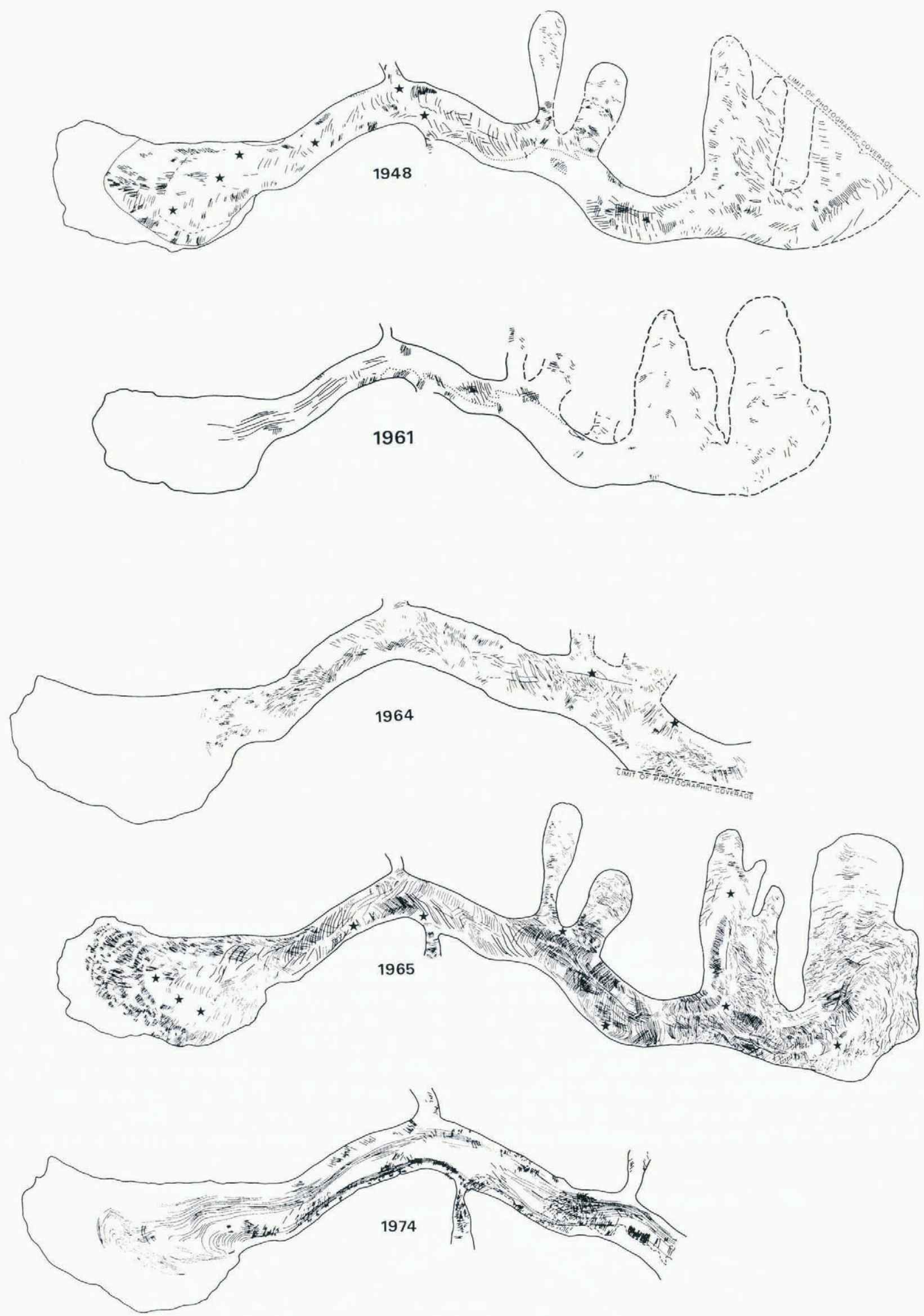

Fig. 2. Structural maps of Variegated Glacier based on aerial photographs. The continuous flow-parallel lines (e.g. in 1961 and 1974) are foliations. The dotted line on each map indicates the position of the snow-line at the time of photography. Stars indicate those parts of the glacier that were so intensely and chaotically crevassed that individual crevasse orientations could nol be identified. For approximale scale see Figure 1. 

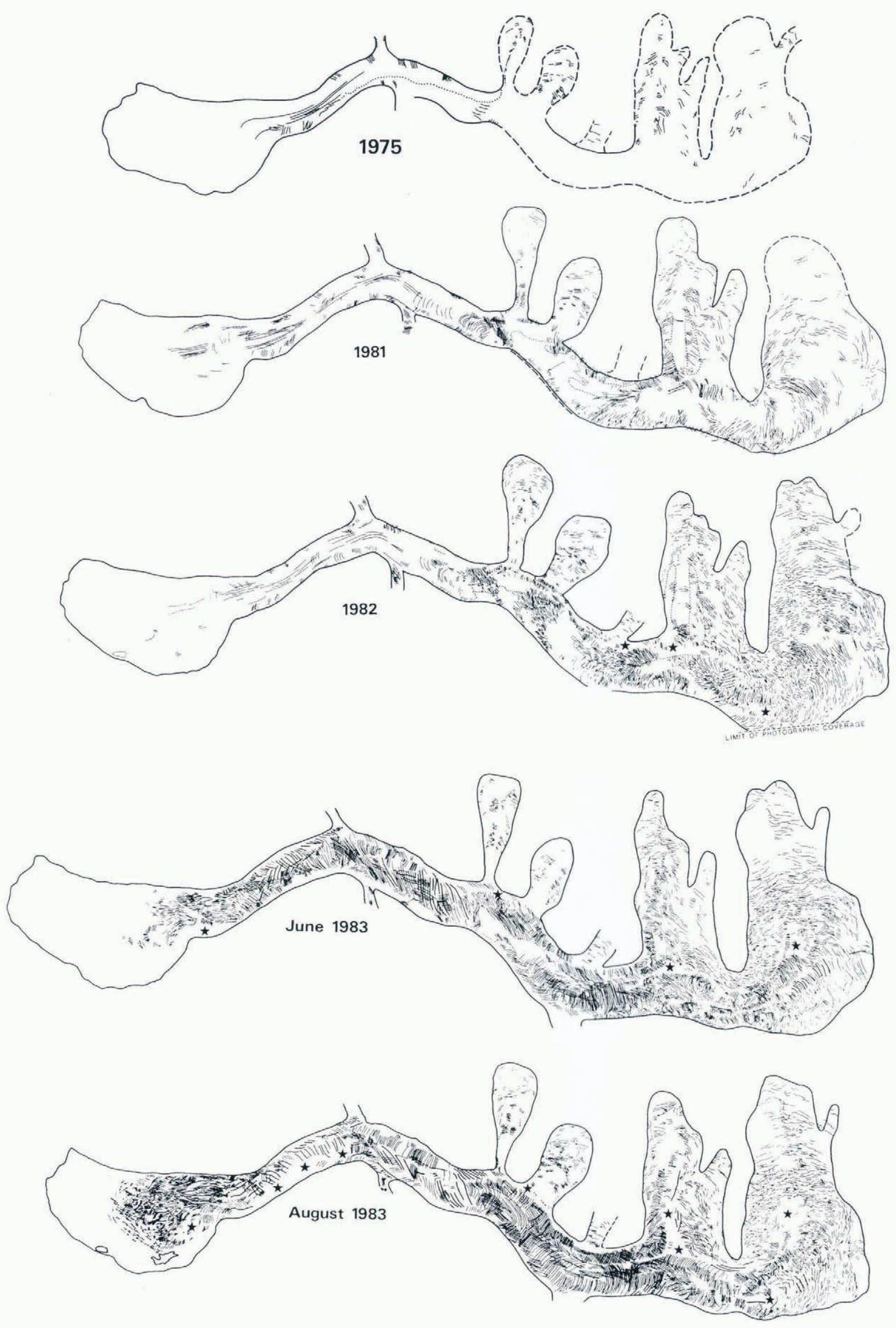

structural analyses of Variegated Glacier, using these field observations as detailed ground control for a large-scale glacier-wide structural analysis of Variegated Glacier based on a series of 12 sets of vertical aerial photographs taken since 1948. This series, and the analysis derived from it, span a period which incorporates two complete surge cycles and three surges. The principal aims of this paper, then, are: (1) to examine glacier-wide structural 
patterns at Variegated Glacier since 1948, (2) to evaluate the extent to which successive surges and surge cycles have produced similar sets of structures, and (3) where possible, to use structural patterns and features to make inferences about large-scale behaviour. Although deformation is not discussed quantitatively or in any detail in this paper, the extent to which structural patterns reflect what is known about the patterns of deformation at the surface of Variegated Glacier (see Kamb and others, 1985; Sharp and others, 1988; Lawson, 1989) is evaluated where appropriate.

The surge history of Variegated Glacier since 1948 is well known, both from direct field observations and from aerial photography (Post, 1969; Bindschadler and others, 1977; Lawson, 1989). A surge in 1947-48 had just finished at the time of the first vertical aerial photographic survey in late June 1948, and surges have occurred since in 1964 65 and 1982-83. The nature of the dynamics of the 198283 surge is known from field observations (Kamb and others, 1985; Raymond and others, 1987). The surge occurred in two phases, the first from January to June 1982 and the second from October 1982 to July 1983. The first phase affected only ice in the upper three-fifths of the glacier, down to about $12 \mathrm{~km}$ from the head of the glacier on the centre line (Fig. 1). During the second phase the surge-phase velocity maximum moved down-glacier through the ice at the crest of a topographic wave, at speeds faster than the ice motion itself.

\section{STRUCTURAL MAPS}

The 12 sets of vertical aerial photographs of Variegated Glacier have been taken at various heights and at various stages in the surge cycle since 1948. Ten of these sets have been used to create a time series of maps of structures visible on the surface of the glacier at the time of the surveys (Fig. 2), and the remaining two sets have been examined in detail. These ten structural maps (Fig. 2) form the basis of the analysis presented in this paper. Also included for illustration and reference are aerial photographic images of the lower half of the glacier immediately after the 1947-48, 196465 and 1982-83 surges (Fig. 3). Where specific structures are cited in the following discussion, their position on the glacier is referred to in terms of the distance downstream from the head of the glacier in kilometres (Fig. 1).

The period of aerial photography spans two complete surge cycles (post-surge 1948 to post-surge 1983), as outlined above. During this time, most stages of the surge cycle have been captured by aerial photographic surveying in more than one surge cycle. The immediate post-surge state has been captured for the three most recent surges (see Fig. 3), whilst the mid-quiescent state has only been captured for the most recent complete cycle (in 1974). Largely because of this uneven timing of the aerial photographic surveys with respect to the surge cycle, and also as a result of the scale and coverage of surveys conducted at different times (see Lawson, 1989, p. 240), the structural interpretations presented in this paper are probably most accurate and most generally representative for surge phases.

The types of structure identifiable on aerial photo- graphs depend on four factors: (i) the scale of the photographs, (ii) the intensity of crevassing of the glacier surface, (iii) the extent of snow cover at the time of the photographic survey, and (iv) the degree of ground control available. Crevasse orientations can be identified with ease in most cases, except where the surface is chaotically crevassed. On larger-scale photographs, individual crevasses can be seen. In inactive ice, foliation and other planar structures can be recognised as long as the ice is not heavily crevassed. Structural observations made during the 1982-83 surge (Sharp and others, 1988) and during 1986 and 1987 (Lawson and others, 1994) provide wide-ranging and detailed ground control for the analysis of aerial photographs, enabling reliable identification of structures other than crevasses. In summary, then, during and after surges, crevasse orientations and some individual crevasses can be identified except where the surface is so chaotically crevassed that not even orientations are discernible. During quiescence, crevasses can be seen, as well as the detail of crevasse traces and foliations.

The way in which the rest of this paper is organised reflects both the nature of structures that can be identified on aerial photographs and the types of inferences that can be made as a result. Thus, the next three sections deal systematically with the development and patterns of various structures at various times in the surge cycle (surge-phase crevasse patterns; quiescent-phase crevasse patterns; other planar structures). The subsequent three sections address particular aspects of the behaviour and evolution of Variegated Glacier that are of interest either because they elucidate issues that have been raised by previous workers at other surge-type glaciers (moraine patterns and structural features; behaviour of tributaries), or because of what they tell us about the behaviour of Variegated Glacier in particular (structures at the accumulation-basin confluence).

\section{SURGE-PHASE CREVASSE PATTERNS}

The surface of Variegated Glacier during and immediately after all three of its most recent surges was intensely crevassed (Figs 2 and 3). The nature of the crevassing varied across the glacier, and included (i) closely spaced fractures giving the ice a powdered appearance on photographs, (ii) huge chasms extending across the width of the glacier, and (iii) crevassing so chaotic that orientations cannot be distinguished on photographs (Figs 2 and 3). The spatial distribution of each type of crevasse assemblage was similar for all three surges. The largest chasms occurred mainly in the lower part of the glacier. In 1983 they were developed in areas lying between 10.5 and $12.0 \mathrm{~km}$ and below about $13.0 \mathrm{~km}$ from the head of the glacier. In 1965, chasms were developed everywhere below $10.5 \mathrm{~km}$, and the belt in which chasm formation was most intense meandered across the valley like the thalweg of a river.

The crevasse orientations at the end of all three surges displayed a distinct three-fold longitudinal zonation. The general nature of this zonation is summarised schematically in Figure 4, and the locations of the zone boundaries at the end of each surge are indicated in Figure 5. The nature of this zonation is as follows: 

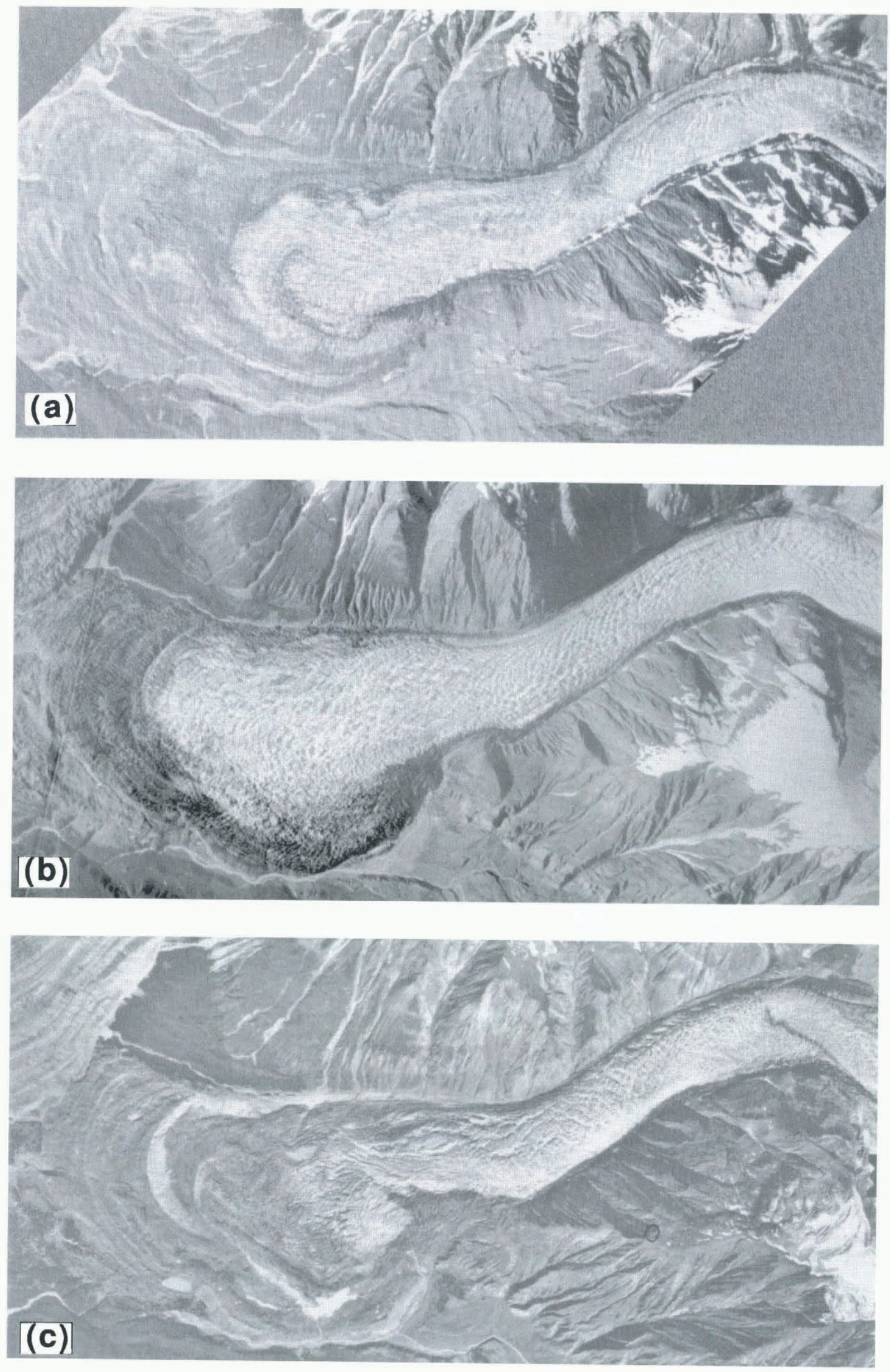

Fig. 3. Aerial photographs of the lower part of Variegated Glacier in its immediate post-surge state for the last three surges: (a) after the 1947-48 surge; (b) after the 196465 surge; (c) after the 198283 surge. 

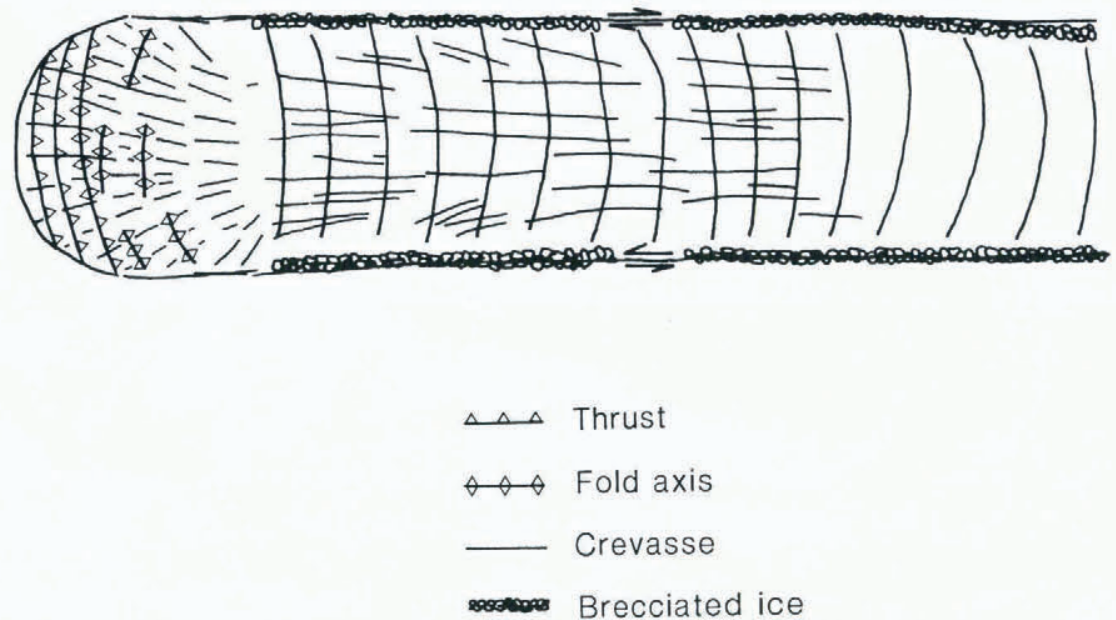

Fig. 4. A schematic diagram showing the three-fold post-surge zonation of crevasse orientations at Variegated Glacier. This zonation is apparent in aerial photographs taken after the terminations of its three most recent surges. Other structures that were observed in the field after the 1982-83 surge are also shown.
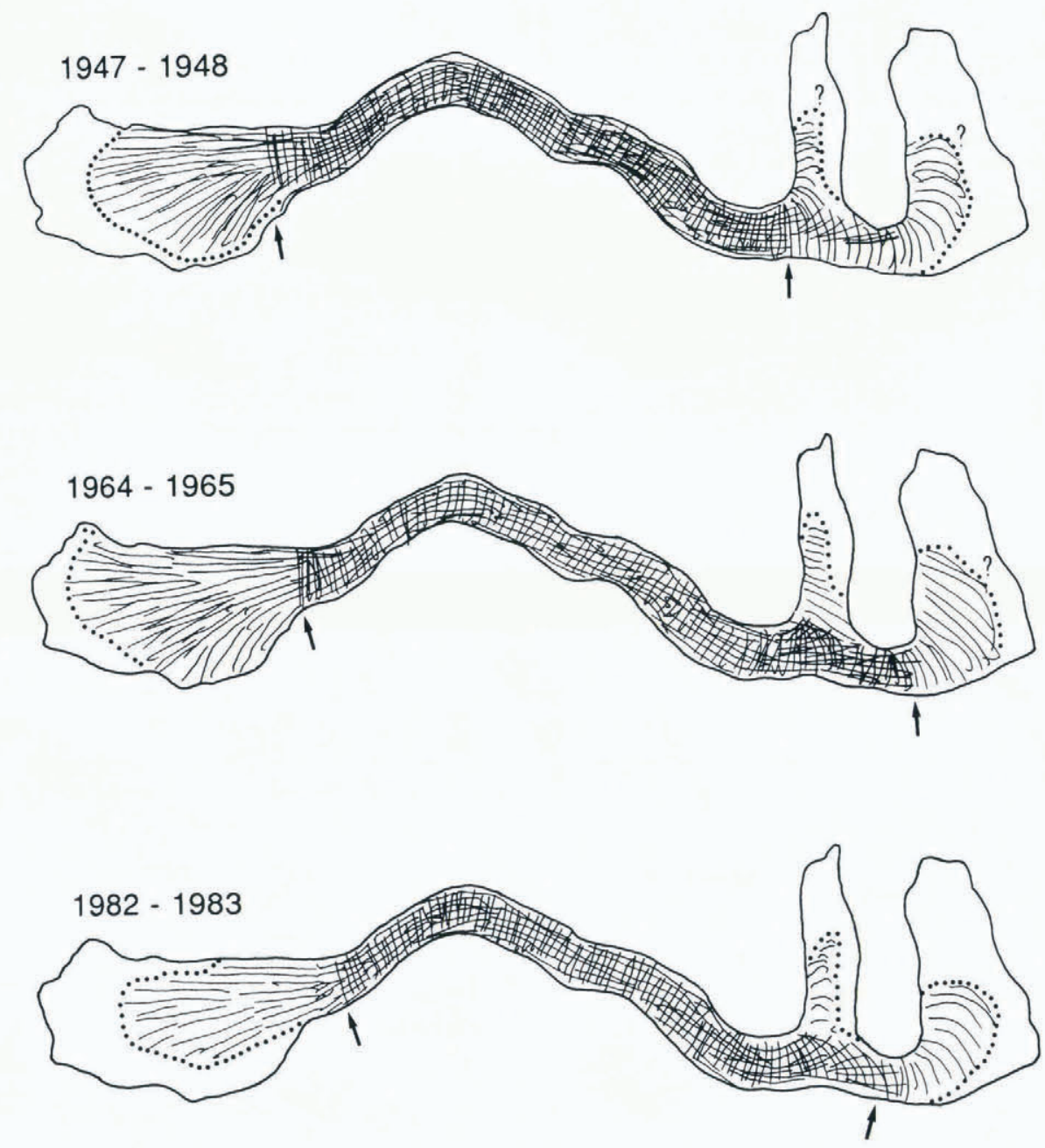

Fig. 5. Summary of the locations of the three crevasse zones at the end of the three most recent surges of Variegated Glacier.

1. In an upper zone, above the surge nucleus in the accumulation area, transverse crevasses dominate. They are arcuate and concave down-glacier, and the seracs between them show evidence of buckling towards their centre where ice is compressed laterally as it flows from the wide accumulation basin into the narrow confined glacier. The secondary accumulation basin, from which ice joins that from the main basin at about $5.0 \mathrm{~km}$ from the glacier head (Fig. 1; see discussion below), is intensely but unevenly crevassed during surges. 
2. An extensive middle zone with a complex crevasse pattern consisting of two or more intersecting sets of crevasses comprises most of the glacier at the end of each surge. Much of the surface of this part of the glacier is so intensely crevassed that individual crevasse orientations cannot be identified. However, where crevassing is least intense a characteristic pattern of superimposed longitudinal and transverse crevasses can be identified, in which cross-cutting relationships indicate that the longitudinal set predates the transverse set. This observation is confirmed by field analysis.

3. In a relatively short lower zone at the down-glacier limit of surge activity, straight longitudinal crevasses predominate. In the lowermost few hundred metres of this zone, crevasse development is typically patchy, and in some cases only occurs on topographic highs.

Syntectonic observations of tectonic processes in the terminal lobe area during the 1982-83 surge indicate that the glacier-wide zonation of crevasse direction was also reflected in the zonation and distribution of other types of structure such as folds and faults (see Sharp and others, 1988; Lawson and others, 1994). In addition, within the lowermost zone of longitudinal crevasses (see 3 above), there was a sub-zonation of compressive structures which reflected the pattern of decreasing ice depth in the terminal lobe.

The zonation of crevasse orientation reflects the observed wave-like mechanics of the propagation of the surge through Variegated Glacier (Kamb and others, 1985; Raymond and others, 1987). As the velocity peak associated with the surge moved down-glacier through the ice, the ice was first compressed ahead of the velocity peak and then extended behind it. Ice that was passed by the surge front, namely ice in the middle zone as outlined above, consequently developed longitudinal crevasses and then transverse crevasses. Ice that lay down-glacier of the final position of the velocity peak, that is ice in the lower zone, only underwent longitudinal shortening, and therefore developed only longitudinal crevasses. Ice above the point at which the velocity peak began its down-glacier motion, that is ice in the upper zone, was only elongated, and consequently only developed transverse crevasses.

The effects of valley and glacier geometry are superimposed on those resulting from the propagation of the surge. Thus, where flow diverges into the terminal lobe, so too do the crevasse orientations, so that longitudinal, or more correctly flow-parallel, crevasses fan out from the confined part of the glacier.

During surges, the margins of the glacier are intensely sheared. Field observations of the detailed pattern of structural development in the $250 \mathrm{~m}$ wide marginal shear zone during the 1982-83 surge are summarised in Figure 6 . The margin-parallel zonation of crevasse orientation developed first as the surge front approached, and the wrench fault denoted by the breccia zone (Fig. 6) developed subsequently as the surge front passed and ice became fully incorporated into the surging part of the glacier. At the end of the 1964-65 surge, the marginal shear zones as seen on aerial photographs were very similar to those at the end of the 1982-83 surge, with a zone of brecciation located about $50 \mathrm{~m}$ from the ice margins. This similarity in form suggests a pattern of development of the marginal shear zone during the 1964 65 surge similar to that outlined for the 1982-83 surge.

\section{QUIESCENT-PHASE GREVASSE PATTERNS}

Quiescent ice in the lower part of the glacier is generally inactive and uncrevassed. In the terminal lobe there is no evidence whatsoever of crevasse development in quiescent ice. Even after the first phase of the 1982-83 surge, which ended in June 1982, the terminal lobe remained unaffected by the intense activity further up-glacier (Fig. 2, map for 1982). Other parts of the glacier display limited crevasse development at certain times in quiescence which, for the most recent phase of quiescence, can be explained in terms of what is known about the quiescent-phase deformation regime, as presented by Lawson (1989). These relationships are outlined below.

Narrow straight transverse crevasses extended across the glacier in 1974 in a zone $9.0-10.5 \mathrm{~km}$ from the head of the glacier they may have existed up-glacier of here; $9.0 \mathrm{~km}$ was the limit of photographic coverage in this survey as shown in Figure 2). The presence of these crevasses reflects the fact that ice at this location in 1974 lay in a zone of longitudinal elongation (Lawson, 1989). By 1981 these initially straight crevasses had been deformed into an arcuate concave up-glacier shape at $10.0 \mathrm{~km}$. Splaying crevasses (Meier, 1960), which are longitudinal in the centre of the glacier and curve towards the margins down-glacier, had also formed by 1981 in an area located at $6.5-7.0 \mathrm{~km}$. This area was experiencing progressively intensifying longitudinal shortening at this time, in the build-up to the impending surge (Lawson,

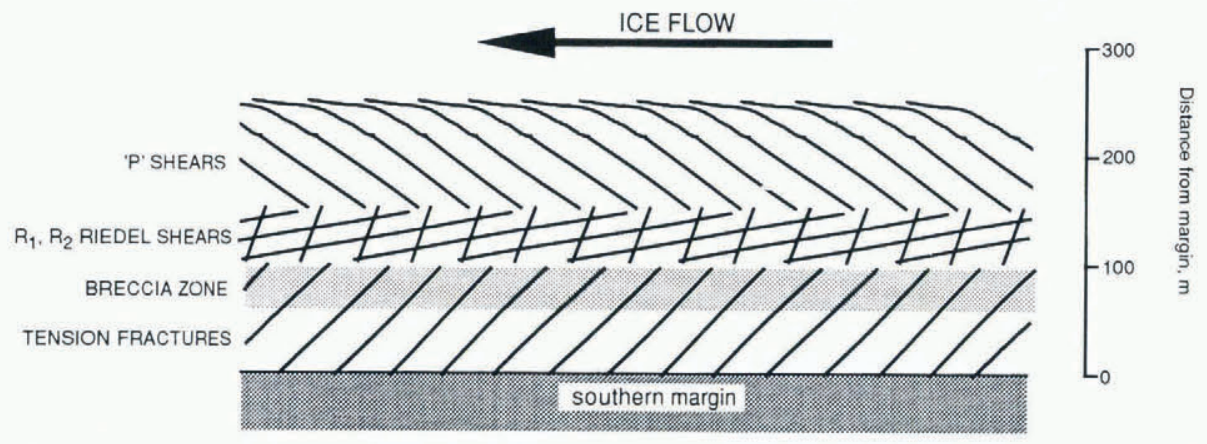

Fig. 6. A schematic diagram showing the marginal shear zone which developed during the 1982 - 83 surge of Variegated Glacier, and which also developed during the 1964-65 surge. The breccia zone was the last to form. This figure is based on observations presented in Sharp and others (1988), and on observations from aerial pholographs. 
1989). The splaying shape is characteristic of crevasse development in a regime combining longitudinal shortening with transverse shear (Nye, 1952), and is therefore consistent with the calculated deformation field.

Fields of en échelon crevasses form at the margins of the quiescent glacier, with orientations consistent with those of en échelon tension fractures forming in ductile shear zones (Ramsay, 1980). These crevasses make an acute angle of about $45^{\circ}$ with the margin upstream. They occur especially near tributary confluences (e.g. on north margin at $9.3 \mathrm{~km}$ in 1961; Fig. 2) and in the vicinity of bends in the valley (e.g. on north margin at $12.8 \mathrm{~km}$ in 1975; Fig. 2), in areas where shear is enhanced. After formation, some of these crevasses rotate in continued shear and are deformed into an arcuate concave up-glacier shape (e.g. at $9 \mathrm{~km}$ on north margin in 1981; Fig. 2; cf. Vornberger and Whillans, 1990 ), or in some instances seracs between them buckle (e.g. at $6 \mathrm{~km}$ on north margin in 1981; Fig. 2).

The accumulation basins are always somewhat crevassed, even in the midst of quiescence, because of the relatively steep gradient of this part of the glacier bed (see Bindschadler and others, 1977). The differences between crevasse patterns in 1975 and 1981 indicate that the degree of crevassing in the accumulation basins increases markedly in late quiescence. The contrast between the scales of, and extent of snow cover on, the photographs for 1975 and 1981 precludes definitive conclusions, but the intensification of crevasse development is consistent with the increasingly steep downglacier velocity gradient associated with the gradual build-up to the surge (Raymond and Harrison, 1988). Transverse crevasses in the upper reaches of the main accumulation basin at about $3-4 \mathrm{~km}$ are generally concave down-glacier (e.g. in 1981; Fig. 2) as a result of the effects of transverse shear (Nye, 1952).

\section{OTHER PLANAR STRUCTURES}

A pervasive longitudinal foliation is often visible in quiescent ice (Fig. 2; 1961, 1974). The pattern of outcrop of this foliation and its relationship to flow patterns is complex. In the confined part of the glacier, the foliation is parallel to the flow direction. The folia are more closely spaced on the outside of bends where a component of the flow from upstream is directed towards the margin (e.g. the north margin at $10 \mathrm{~km}$ in 1974; Fig. 2 . In the terminal lobe, the foliation loses its flowparallel orientation and becomes folded, along with the medial moraines.

The relationship between the orientation of the longitudinal foliation and that of lineaments in medial moraines is also complex. In the confined glacier, the foliation usually lies parallel to the supraglacial debris lineaments, except where the medial moraines are looped. In these locations, foliation remains parallel to flow, and intersects the debris lineaments. However, as indicated above, when the moraines become folded in the terminal lobe, so too does the longitudinal foliation. The nature and origin of this folding is discussed in the following section.

The origin of the foliation presents an explanation for these complex relationships between structural, flow and debris lineaments. Field structural relationships indicate that the origin of this longitudinal foliation is related to intense transverse shear, and that the folia consist either of folded sedimentary layering, or of slip planes that are parallel to these folded layers (Lawson and others, 1994). As ice moves out of the narrow, confined part of the glacier and into the broad, unconfined terminal lobe, the intensity of transverse shear decreases. It is suggested that whereas longitudinal foliation is an actively developing structure in that part of the glacier which is confined by the valley walls, in the terminal lobe the longitudinal foliation becomes inactive, and essentially comprises a relict structure: as ice in the terminal lobe is subsequently deformed, the foliation acts simply as a passive marker.

Another planar structure that is widespread and that occurs in groups is spaced, transverse, arcuate structures similar in morphology to those described at other nonsurging glaciers (e.g. at Blue Glacier in Washington, U.S.A. (Allen and others, 1960); Gulkana Glacier in Alaska (Ragan, 1969); Griesgletscher in Switzerland (Hambrey and Milnes, 1977); and White Glacier in the Canadian Arctic (Hambrey and Müller, 1978)). These features are concave up-glacier and often occur in areas which lie down-glacier of transverse crevasse fields, such as those located $10.5 \mathrm{~km}$ from the glacier head in 1981 (Fig. 2). These latter features are derived from crevasses formed in an area of the glacier (at 9-10.5 km; see above) that was experiencing longitudinal elongation a few years previously. By 1981, however, the whole glacier was experiencing longitudinal shortening (Lawson, 1989), and hence the open transverse fractures had closed up. These arcuate structures are therefore crevasse traces which originated as transverse crevasses and which have closed up since their formation and become deformed into arcuate structures, in the manner described by Hambrey and Milnes (1977, p. 672).

\section{MORAINE PATTERNS AND STRUCTURAL FEATURES}

Much of the debris at the surface of Variegated Glacier originates as medial moraines at confluences in the accumulation area. The lineaments of this debris are therefore generally mutually sub-parallel and, in the confined part of the glacier, parallel to the flow direction. Where the debris has been deposited onto the glacier during mass-flow events, it is superimposed upon and intersects other debris lineaments. As ice moves into the terminal lobe the supraglacial moraines, like the longitudinal foliation, act as passive markers and lose their flow-parallel orientation.

The confluences of tributaries at the north margin have resulted in the bulb-like loops in the medial moraines. Similar loops are found at many surge-type glaciers, and are both typical and diagnostic of surge-type glaciers (Post, 1972; Driscoll, 1980). There is no evidence to indicate that any of the tributaries of Variegated Glacier surge (see below), which suggests that like the moraine loops at Bering Glacier, also in southeast Alaska, the moraine loops at Variegated Glacier form during quiescence when the main trunk glacier is essentially stationary (Post, 1972). At other surge-type glaciers whose tributaries surge such as Klutlan Glacier, Yukon 
(Driscoll, 1980), moraine loops form as a result of surges of the tributary.

In the terminal lobe the medial moraines are folded into large-scale tight to isoclinal folds with steeply dipping hinge lines and axial planes transverse to flow (Sharp, 1988, fig. 1). These folds develop in response to the longitudinal shortening and transverse elongation which occurs in the terminal lobe. They form by the amplification of preexisting irregularities in the moraines by passive folding (cf. Hudleston, 1976). Moraine patterns in successive years (Lawson, 1989) indicate that, whilst the tightening of these folds is imperceptible during quiescent phases, the moraines are folded rapidly during surges. This photographic evidence for rapid fold development during surges is supported by observations of the deformation of a linear array of markers in the terminal lobe during the 1982-83 surge (Raymond and others, 1987). As the initially linear array was affected by the approaching surge front, it was folded by the surge over a 2 month period into a fold with a style very similar to that of the folds in the medial moraines (Raymond and others, 1987, fig. 1).

\section{BEHAVIOUR OF TRIBUTARIES}

Like the main accumulation basins, the tributaries are always crevassed to some extent because they are relatively steep. However, none of the tributaries display any significant changes in intensity or pattern of crevasse development from year to year, and there is no other photographic or field evidence to suggest that any of them surge at any time. It is therefore inferred that none of the tributaries of Variegated Glacier surge, either synchronously with, or independently of, the main glacier.

A detailed field structural survey of ice within a moraine loop in the terminal lobe derived from the tributary located on the north side of the glacier at 9.5$10.0 \mathrm{~km}$ (Lawson, 1989) indicates that after tributary ice enters the main valley, it becomes structurally incorporated into the trunk glacier. Even those fractures which must have formed whilst the ice was located in the parent tributary were not distinguishable in the field from those that had formed since its confluence.

\section{STRUGTURES AT THE AGCUMULATION-BASIN CONFLUENGE}

Ice flowing from the two major accumulation basins meets at a right-angled confluence about $5.0 \mathrm{~km}$ from the head of the glacier (Fig. 1). Crevasse patterns indicate that during quiescence ice across the whole width of both basins is equally active. During surges, however, activity is spatially and temporally variable. Ice across the whole width of the main (easterly) basin flows rapidly, whilst only the westerly part of ice in the secondary basin flows rapidly. This reflects the cross-sectional geometry of this westerly basin, which comprises a $200 \mathrm{~m}$ deep selfcontained channel in the western third of the basin and shallow and stagnant ice to the east Bindschadler and others, 1977, figs 3 and 5 ).

The suture between the two ice units derived from the two accumulation basins is marked by a medial moraine and, during surges, by a deep longitudinal chasm, which at the termination of surges extends about $3 \mathrm{~km}$ downglacier of the confluence (Fig. 2). The lateral position of the suture is generally such that the ratio of the contributions of the main and secondary accumulation basins to the total width of the glacier is approximately $2: 1$. At the end of the 1964-65 surge, the post-surge suture was stepped, such that $1 \mathrm{~km}$ down-glacier of the confluence the main basin contributed $70 \%$ of the total glacier width, but $300 \mathrm{~m}$ further down-glacier, only $60 \%$. This shift in the position of the suture indicates that at some stage in the 1964-65 surge, the main basin suddenly began to contribute a greater proportion of the total flux. This observation may indicate that the secondary accumulation basin stopped surging earlier than the main accumulation basin, perhaps because its smaller ice volume was exhausted first.

The extent to which the ice units from the two accumulation basins remain structurally autonomous as they move down-glacier is hard to assess. As indicated above, ice from tributaries further down-glacier becomes structurally incorporated into the main body of the glacier. The nature of the suture between ice from the two accumulation basins as outlined in the preceding paragraph indicates that the two ice units are autonomous in the confluence area during surges. Similarly, there are some structural features visible further downglacier whose morphology indicates that they are related to deformation within a given ice unit rather than across the width of the glacier. For example, some arcuate crevasse traces (e.g. on the south side of the glacier at $10.5 \mathrm{~km}$ in 1982; Fig. 2) span only the part of the glacier derived from the main easterly basin. Also, the pattern of outcrop of the longitudinal foliation in 1974 appeared to consist of two distinct units in some places (e.g. vicinity of $13 \mathrm{~km}$; Fig. 2). In general, though, contiguous crevasse development across the whole width of the glacier, both during surges and during quiescence, indicates that the two ice units are structurally coherent downstream of the confluence zone. This inference is supported by the lack of evidence, either in velocity profiles or in cross-sectional morphology (Bindschadler and others, 1977, figs 3 and 5), to suggest that the units remain kinematically independent down-glacier of their union.

In summary, it seems that although the ice units that flow out of the two accumulation basins during a surge are structurally independent during that surge, in general and further down-glacier the ice units behave in a structurally coherent manner. Structures whose morphology is related to only one of the units are therefore inferred to be related to deformation within one of the accumulation basins prior to the arrival of the ice at the confluence $5 \mathrm{~km}$ from the head of the glacier.

\section{DISCUSSION AND GONGLUSIONS}

The large-scale structural glaciology of Variegated Glacier at all stages in its surge cycle is dominated by features related to its surge-type flow regime. Even in mid-quiescence, when the ice is essentially stationary and largely crevasse-free, bulb-like loops in moraines and large-scale folds in the terminal lobe serve as reminders of 
the surge nature of the glacier. The three-dimensional geometry of the glacier, which is the main influence on the structural glaciology of normal glaciers (Allen and others, 1960; Meier, 1960; Hambrey, 1976; Hambrey and Müller, 1978), exerts some influence especially in the terminal lobe, in the region of sharp bends and as a result of the accumulation-basin morphology, but its surge-type regime is the overriding influence.

Since 1948, successive surges and surge cycles have produced very similar sets and patterns of structures, despite variation in the extent and intensity of the surges (Lawson, 1989). At the end of each of the three recent surges, the crevasse pattern comprised a characteristic three-fold longitudinal zonation, with longitudinal crevasses at the down-glacier end of the affected ice, transverse crevasses at the up-glacier end, and a complex superimposed pattern between. The pattern and types of structure developed in the marginal detachment zone during the two most recent surges were also very similar.

The glacier is largely structurally inactive during its quiescent phase. The crevassing that develops during quiescence is mostly a function of the build-up to the next surge, although some occurs independently as a result of a reversal of the down-glacier velocity gradient in the central part of the glacier.

Variegated Glacier's main and secondary accumulation basins generally contribute ice to the total width of the glacier in about a $2: 1$ ratio (see discussion above). Below the confluence, ice from the two basins generally acts as one, both dynamically and structurally. Relict structures derived from deformation within one or other of the accumulation basins may be preserved in either of the two units. The morphology of the confluence zone suggests that during certain surges the supply of ice from the smaller secondary basin may be exhausted before that from the main accumulation basin, as evidenced by the abrupt change in the proportions that each contributed to the total width of the glacier during the 1964-65 surge. There was no evidence for such a change in either the 1947-48 or the 1982-83 surge; it may be that the greater intensity of the 1964-65 surge (see Lawson, 1989) resulted in this exhaustion.

In the terminal lobe, the longitudinal foliation which forms further up-glacier as a result of margin-parallel shear becomes a passive structure, which continues to exist but is essentially a relict feature.

There is no evidence to suggest that any of the tributaries of Variegated Glacier surge. Since the tributaries of Variegated Glacier are both short $(<2 \mathrm{~km}$ long) and steep, this finding is consistent with work that indicates that longer ice bodies are more likely to be surge-type (Clarke and others, 1986; Clarke, 1991) and that low slopes favour surging (Kamb, 1987).

\section{AGKNOWLEDGEMENTS}

I am indebted to W. Harrison for the opportunity to examine photograph sets of Variegated Glacier and to discuss its history with him during a visit to the University of Alaska Fairbanks. I am also very grateful to A. Post for the opportunity to view his unpublished and inimitable structural maps of Variegated Glacier, and to discuss the structural history of the glacier with him. M. Hambrey in particular, and W. Harrison and two anonymous referees, made many useful comments on an earlier draft of the paper, as a result of which its clarity has been substantially improved. M. Sharp and M. Hambrey both provided invaluable assistance throughout the course of this work. This work was conducted with the support of a U.K. Natural Environment Research Council Research Studentship.

\section{REFERENCES}

Allen, C. R., W. B. Kamb, M. F. Meier and R. P. Sharp. 1960. Structure of the lower Blue Glacier, Washington. J. Geol., 68 (6), 601-625.

Bindschadler, R., W. D. Harrison, C.F. Raymond and R. Crosson. 1977. Geometry and dynamics of a surge-type glacier. F. Glaciol., 18 (79), 181-194.

Clarke, G. K.C. 1991. Length, width and slope influences on glacier surging. J. Glaciol., 37 (126), 236-246.

Clarke, G. K. C., J. P. Schmok, C.S. L. Ommanney and S. G. Collins. 1986. Characteristics of surge-type glaciers. J. Geophys. Res., $91(\mathrm{~B} 7)$, $7165-7180$.

Driscoll, F. G., Jr. 1980. Formation of the neoglacial surge moraines of the Klutlan Glacier, Yukon Territory, Canada. Quat. Res., 14(1), 19 30 .

Hambrey, M.J. 1976. Structure of the glacier Charles Rabots Bre, Norway. Geol. Soc. Am. Bull., 87 (11), 1629-1637.

Hambrey, M.J. and A. G. Milnes. 1977. Structural geology of an Alpine glacier Griesgletscher, Valais, Switzerland). Eclogae Geol. Helv., 70 (3), 667-684.

Hambrey, M.J. and F. Müller. 1978. Structures and ice deformation in the White Glacier, Axel Heiberg Island, Northwest Territories, Canada. J. Glaciol., 20 (82), 41-66.

Hudleston, P.J. 1976. Recumbent folding in the base of the Barnes Ice Cap, Baftin Island, Northwest Territories, Canada. Geol. Soc. Am. Bull., 87 (12), $1684-1692$.

Kamb, B. 1987. Glacier surge mechanism based on linked cavity configuration of the basal water conduit system. \%. Geophys. Res., 92 (B9), 9083-9100.

Kamb, B. and 7 others. 1985. Glacier surge mechanism: 1982-1983 surge of Variegated Glacier, Alaska. Science, 227 (4686), 469-479.

Lawson, W. 1989. The structural evolution of Variegated Glacier, Alaska. (Ph.D. thesis, University of Cambridge.)

Lawson, W.J., M.J. Sharp and M.J. Hambrey. 1994. The structural geology of a surge-type glacier. J. Struct. Geol., 16 10), 1447-1462.

Meier, M.F. 1960. Mode of flow of Saskatchewan Glacier, Alberta, Canada. U.S. Geol. Surv. Prof. Pap. 351.

Nye, J. F. 1952. The mechanics of glacier flow. 7. Glaciol., 2 (12), 82-93.

Pfeffer, W. T. 1992. Stress-induced foliation in the terminus of Variegated Glacier, Alaska, U.S.A., formed during the 1982-83 surge. J. Glaciol., 38 (129), 213-222.

Post, A. 1969. Distribution of surging glaciers in western North America. f. Glaciol., 8 53 ), 229-240.

Post, A. 1972. Periodic surge origin of folded medial moraines on Bering piedmont glacier, Alaska. J. Glaciol., 11(62), 219-226.

Ragan, D. M. 1969. Structures at the base of an ice fall. J. Geol., 77(6), $647-667$.

Ramsay, J. G. 1980. Shear zone geometry: a review. J. Struct. Geol., 2(1), 8399.

Raymond, C. F. and W. D. Harrison. 1988. Evolution of Variegated Glacier, Alaska, U.S.A., prior to its surge. f. Glaciol., 34(117), 154-169.

Raymond, C., T. Jóhannesson, T. Pfeffer and M. Sharp. 1987. Propagation of a glacier surge into stagnant ice. J. Geophys. Res., 92 B9), 9037-9049.

Sharp, M. 1988. Surging glaciers: geomorphic effects. Prog. Phys. Geogr., $12(4), 533-559$.

Sharp, M., W. Lawson and R. S. Anderson. 1988. Tectonic processes in a surge-type glacier. J. Struct. Geol., 10(5), 499-515.

Vornberger, P. L. and I. M. Whillans. 1990. Crevasse deformation and examples from Ice Stream B, Antarctica. 7. Glaciol., 36 (122), 3-10. 